\title{
Disruption of Steroid Axis, a New Paradigm for Molar Incisor Hypomineralization (MIH)
}

\author{
Sylvie Babajko ${ }^{1,2 *}$, Katia Jedeon ${ }^{1,2}$, Sophia Houari, ${ }^{1,2}$, Sophia Loiodice ${ }^{1,2}$ and \\ Ariane Berdal ${ }^{1,2,3}$ \\ ' Laboratory of Molecular Oral Pathophysiology, Centre de Recherche des Cordeliers, Institut National de la Santé et de la \\ Recherche Médicale UMRS 1138, University Paris-Descartes, University Pierre et Marie Curie-Paris, Paris, France, ${ }^{2}$ Unité de \\ Formation et de Recherche en Odontologie, University Paris-Diderot, Paris, France, ${ }^{3}$ Centre de Référence des Maladies \\ Rares de la face et de la Cavité Buccale MAFACE, Rothschild Hospital, Paris, France
}

Keywords: amelogenesis, MIH, steroid receptors, steroid hormones, endocrine disrupting chemicals, enamel mineralization

\section{OVERVIEW}

OPEN ACCESS

Edited by:

Petros Papagerakis,

University of Michigan, United States

Reviewed by:

Yong-Hee Patricia Chun, University of Texas Health Science Center at San Antonio, United States Harald Osmundsen, University of Oslo, Norway

*Correspondence:

Sylvie Babajko

sylvie.babajko@crc.jussieu.fr

Specialty section:

This article was submitted to Craniofacial Biology and Dental

Research,

a section of the journal

Frontiers in Physiology

Received: 20 March 2017 Accepted: 10 May 2017 Published: 26 May 2017

Citation:

Babajko S, Jedeon K, Houari S, Loiodice $S$ and Berdal A (2017) Disruption of Steroid Axis, a New

Paradigm for Molar Incisor

Hypomineralization $(\mathrm{MIH})$.

Front. Physiol. 8:343.

doi: 10.3389/fphys.2017.00343
Molar-Incisor Hypomineralization (MIH) is a common developmental enamel defect characterized by asymmetric demarcated opacities in permanent molars and incisors. MIH was first described in 2001-2003 (Weerheijm et al., 2001; Weerheijm and Merjare, 2003). It was previously called cheese molars, idiopathic enamel hypomineralization in permanent teeth, included in developmental enamel defects other than that caused by fluoride but the prevalence of these defects was poorly documented except in Sweden where it was first investigated (Koch et al., 1987). It affects now $15-20 \%$ of 6-9 year-old children worldwide but its etiology still remains unclear. MIH is certainly a non-hereditary multifactorial pathology even though an individual hereditary susceptibility to MIH is not excluded as suggested by enamelin gene polymorphism (Jeremias et al., 2013). Several causal factors have been proposed such as prematurity, long breastfeeding, viral or bacterial infections, respiratory diseases, asthma (Alaluusua et al., 2002; Alaluusua, 2010; Serna et al., 2016; Silva et al., 2016; Tourino et al., 2016). None of these factors is satisfactory to explain MIH recent emergence nor its selective enamel lesions on the first mineralizing permanent teeth, mainly permanent first molars and incisors. Despite the fact that mineralization of the other permanent teeth may be delayed, they are rarely affected by MIH. Given that MIH affects those teeth undergoing mineralization around the time of birth, it is clear that the enamel forming ameloblasts are sensitive to the causative agent(s) in a specific time window only. It is noteworthy that MIH emergence is overlaying to increased prevalence of pathologies related to the currently changing environmental conditions with increasing amounts of pollutants. Indeed, our environment and lifestyle are dramatically changing and exposure to novel molecules or combination of factors during the period of amelogenesis may be a possible track. Among environmental toxicants, Endocrine Disrupting Chemicals (EDCs) are exogenous substances or mixtures that alter function(s) of the endocrine system and consequently cause adverse health effects in an intact organism, or its progeny, or (sub) populations (EDC definition established by the World Health organization in 2002). EDCs are small molecules that may share structural homologies with steroid hormones, and are thus able to disrupt steroid axes. Steroid hormones (such as estrogens, androgens, or corticoids for example) mediate their effects through intracellular steroid receptors that modulate transcription of their target genes. Most of steroid receptors are expressed by ameloblasts and thus possibly involved in amelogenesis (Houari et al., 2016). The present paper explores the hypothesis of their involvement in amelogenesis and delineates one mechanistic path that would account for MIH. 


\section{EVIDENCE}

EDCs have often been proposed to contribute to hormonedependent cancers, decreased fertility, diabetes, obesity, and cognitive disorders over the past 50 years (Gore et al., 2015). This hypothesis is supported by a number of recent epidemiological and experimental studies. Among the thousands of EDCs, bisphenol A (BPA) is one of the most active and widely used by the plastic industry and also for dental materials. It may be leached as an active monomer under several conditions (Cooper et al., 2011). Sensitivity to BPA is the greatest during the perinatal period and many pathologies diagnosed during adulthood would result from fetal and perinatal exposure to these molecules (Poimenova et al., 2010; Varayoud et al., 2014; Braun, 2017). Interestingly, this period of time corresponds to the temporal window when the enamel of the human permanent teeth is being formed.

Our recent data showed that human $\mathrm{MIH}$ and BPA exposed rat teeth present similar structural and biochemical characteristics (Jedeon et al., 2013). Both series of teeth present broken enamel in areas where the teeth occlude. In addition, the prismatic structure in human MIH enamel as well as BPA exposed rat enamel was obscured by a covering organic layer (Jedeon et al., 2013) similar to the one reported previously (Jälevik et al., 2005). Among the main enamel matrix proteins, enamelin expression was higher in BPA exposed ameloblasts. Enamelin amount is a central parameter for enamel synthesis as demonstrated by an experimental genetic approach ( $\mathrm{Hu}$ et al., 2014). Indeed, ENAM mutations have been reported in Amelogenesis Imperfecta (AI) (Lindemeyer et al., 2010; Chan et al., 2011), and have been associated with MIH (Jeremias et al., 2013). Specific alleles of ENAM are also associated with high susceptibility to dental caries (Chaussain et al., 2014) and the expression level of enamelin appears to be determinant for the structure and quality of enamel (Hu et al., 2014). Too much or too little enamelin abolishes the formation of enamel crystals and prism structure. BPA has also been shown to decrease KLK4 expression which is involved in the degradation of enamel matrix proteins (Jedeon et al., 2013). KLK4 is a serineprotease that cleaves enamel matrix proteins to permit enamel full and correct enamel mineralization (Bartlett and Simmer, 2014). KLK4 mutations have also been reported in AI (Chan et al., 2011). When KLK4 activity and/or level of expression is reduced, remaining enamel proteins after the maturation process of enamel inhibit normal apatite crystal growth. This second event strengthens the first one by additionally increasing the amount of remaining enamelin in mature enamel. In such case, extraneous proteins such as serum albumin are able to accumulate in the poor quality enamel (Farah et al., 2010) worsening the hypomineralization, finally diagnosed as white opaque spots (Denis et al., 2013).

Human and animal populations are exposed to many EDCs simultaneously. BPA certainly acts in combination with other EDCs or hypomineralizing agents. These molecules do not necessarily share the same structural properties, and act through different signaling pathways and receptors. Consequently, the effects of EDCs combinations are unpredictable. For example, combination of low doses of BPA with low doses of genistein and vinclozolin, two other EDCs, didn't lead to a greater phenotype (Jedeon et al., 2014a) whereas combination of BPA with fluoride increased enamel hypomineralization (Jedeon et al., 2016a). Enamel defects have also been associated to exposure to dioxin (Alaluusua et al., 2004) and PCBs (Jan et al., 2007), two groups of pollutants presenting EDC activity. Interestingly, dioxin and amoxicillin exposures have been proposed as a causal factor of Molar Incisor Hypomineralisation (MIH) (Alaluusua et al., 1999; Laisi et al., 2009). It is noteworthy that both factors increase enamel hypomineralization in the presence of fluoride (Salmela et al., 2011; Sahlberg et al., 2013) and the importance of the perinatal exposure to these agents has been underlined (Alaluusua et al., 2002). Even if fluoride is probably not a causal factor of MIH, experimental fluoride in combination with EDCs was shown to increase enamel hypomineralization (Salmela et al., 2011; Sahlberg et al., 2013; Jedeon et al., 2016a).

A number of EDCs are known to disrupt the steroid axis. BPA, for example, binds ERs (Delfosse et al., 2012), GPR30 (Pupo et al., 2012), and ERR $\gamma$ with high affinity (Liu et al., 2012; abbreviations in Table 1). BPA is also able to, directly or indirectly, modulate the activity of AR, PR, GR, RXR, and PPAR $\gamma$ receptors ( $\mathrm{Li}$ et al., 2015; Rehan et al., 2015). Except PPAR $\gamma$ and ER $\beta$, rodent ameloblasts express all these receptors and their expression levels vary depending on the ameloblast differentiation stage (Houari et al., 2016; Figure 1). Furthermore, we have shown that $\mathrm{ER} \alpha$ is involved in pre-ameloblast proliferation (Jedeon et al., 2014b), and $\mathrm{AR}$ in the enamel terminal mineralization process (Jedeon et al., 2016b). Thus, mediated by these receptors, EDCs such as BPA and vinclozolin may disrupt amelogenesis. GR and VDR are classically associated to amelogenesis and enamel mineralization (Pawlicki et al., 1992; Berdal et al., 1993) and might also play a role in the transmission of EDC effects.

All these data argue for the steroid axis playing a central role in the physiological as well as pathological process of amelogenesis.

TABLE 1 | List of abbreviations cited in the text.

\begin{tabular}{ll}
\hline AhR & Aryl hydrocarbon Receptor \\
Al & Amelogenesis Imperfecta \\
AR & Androgen Receptor \\
BPA & Bisphenol A \\
EDC & Endocrine Disrupting Chemical \\
ER & Estrogen Receptor \\
ERR $\gamma$ & Estrogen Related Receptor $\gamma$ \\
GPR30 & G-Protein-Coupled Receptor 30 \\
GR & Glucocorticoid Receptor \\
KLK4 & Kallikrein-related peptidase 4 \\
MIH & Molar Incisor Hypomineralization \\
PCB & PolyChlorinated Biphenyl \\
PPAR $\gamma$ & Peroxisome Proliferator-Activated Receptor $\gamma$ \\
PR & Prolactin Receptor \\
RAR & Retinoic Acid Receptor \\
RXR & Retinoid X Receptor \\
VDR & Vitamin D receptor \\
&
\end{tabular}




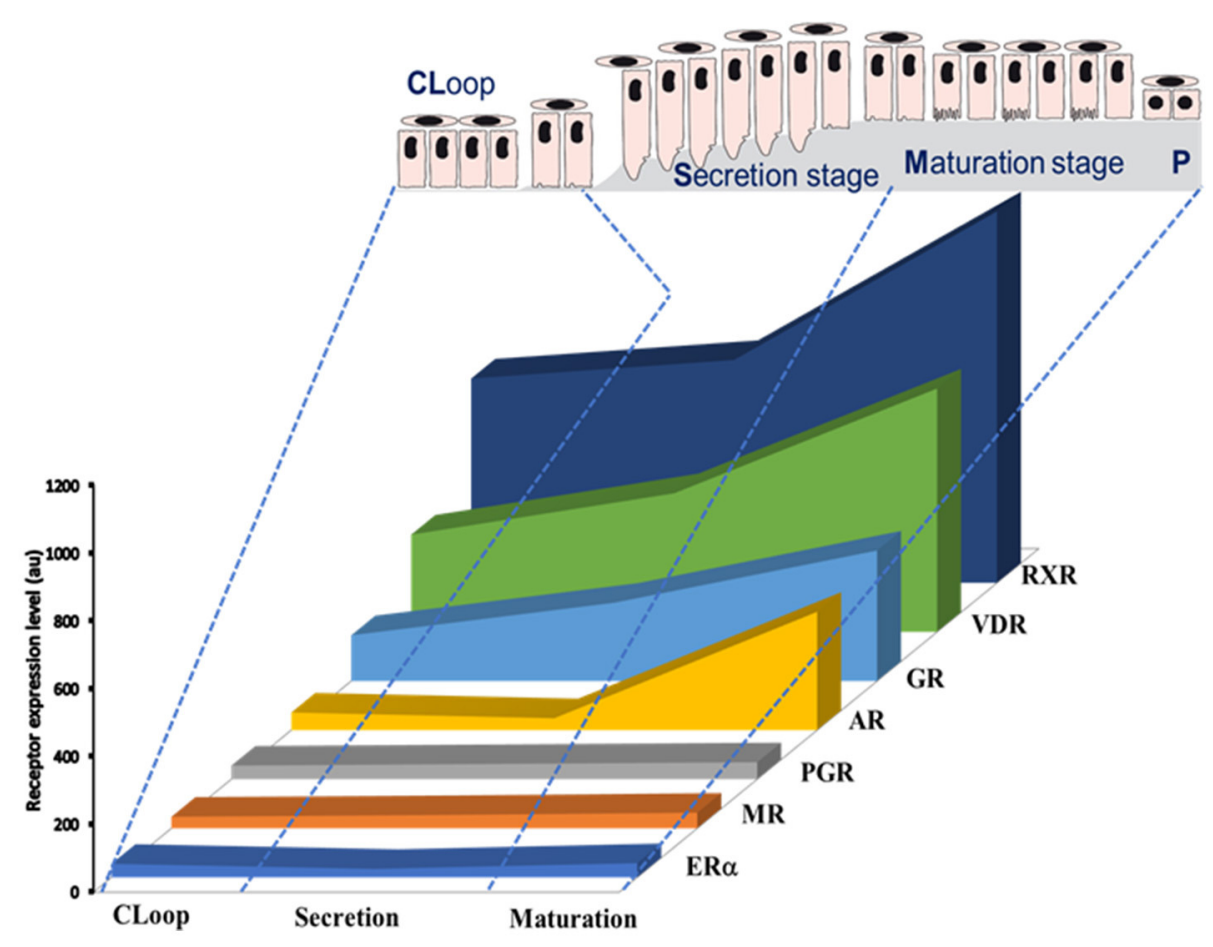

FIGURE 1 | Schematic representation of expression profiles of steroid receptors during amelogenesis based on data published by Houari et al. (2016). The relative level of expression of each mRNA was determined by microarray analysis of RNAs extracted from maturation-stage enamel organ.

The presence of these receptors which expression vary during amelogenesis suggests a stage-specific susceptibility to the corresponding ligands. These may be endogenous molecules like hormones, or exogenous such as vitamins, drugs and EDCs. Otherwise, data reported in the literature showed that many if not all MIH causal factors hypothesized are associated, directly or indirectly, with steroid axis:

Indeed, prematurity and long breastfeeding have been associated to MIH but seem controversial (Alaluusua, 2010; Sönmez et al., 2013). If so, it's worthy to note that milk may accumulate pollutants such as dioxin and PCBs, acting through AhR sharing signaling pathway with ERs (Solomon and Weiss, 2002). On the other hand, premature babies were reported to be contaminated with BPA and phthalates essentially due to medical devices (Calafat et al., 2009; Duty et al., 2013). And, both class of EDCs act via steroid receptors, ERs and AR, reported to modulate enamel key genes like KLK4 (Jedeon et al., 2016b).

$\mathrm{MIH}$ is also associated to infections, otitis, bronchitis, pneumonia, fever and asthma (Tourino et al., 2016). These pathologies are often treated with antibiotics combined to anti-inflammatory molecules as corticoids, acting through GR, which may lead to enamel hypomineralization. There are typical responsive elements to GR in the amelogenin promoter which is a key component of enamel matrix (Gibson et al., 1997) and exposure to corticoids was associated to enamel hypomineralization in rats (Pawlicki et al., 1992).

Deficiency in vitamin A acting through RAR/RXR pathway has been recently associated to $\mathrm{MIH}$ (Mishra and Pandey,
2016). Ameloblasts express retinoid receptors and binding proteins (Bloch-Zupan et al., 1994; Houari et al., 2016) and excess of retinoids disrupt amelogenesis leading to enamel hypomineralization (Morkmued et al., 2017), meaning that the right concentration of retinoids is required at the right moment of amelogenesis. Another vitamin which deficiency was associated to MIH is vitamin D (Kühnisch et al., 2015). It is wellknown that vitamin D binds to the heterodimer VDR/RXR which are the most highly expressed steroid receptors in maturationstage ameloblasts (Figure 1). Vitamin D and VDR are tightly associated to enamel mineralization (Berdal et al., 1993). And, the steady-state mRNA levels of enamel matrix peptides were shown vitamin-dependant in vitamin $\mathrm{D}$ deficient rats which harbored malformed enamel (Papagerakis et al., 2002). In addition, levels of vitamin $\mathrm{D}$ were inversely correlated to BPA contamination (Johns et al., 2016) suggesting a protective role of vitamin $D$ against EDC adverse effects and reinforcing the idea of the importance of steroid axis during the pathophysiology of amelogenesis.

\section{CONCLUSION}

Many of the proposed causal factors for MIH, including EDCs, anti-inflammatory corticoids, vitamin deficiency involve the large family of the steroid receptors. Most of the steroid receptors are expressed in ameloblasts and their levels of expression are dependent on their stage of differentiation. The steroid receptors thus appear as the common elements able to modulate the 
expression of enamel key genes controlling enamel synthesis or leading to enamel hypomineralization in case of disruption.

\section{AUTHOR CONTRIBUTIONS}

SB raised the hypothesis of the paper, drafted and wrote the paper. KJ, SH, and SL did experiments, obtained the results and wrote the corresponding published papers cited in the text. $\mathrm{AB}$

\section{REFERENCES}

Alaluusua, S. (2010). Aetiology of molar-incisor hypomineralisation: a systematic review. Eur. Arch. Paediatr. Dent. 11, 53-58. doi: 10.1007/BF03262713

Alaluusua, S., Calderara, P., Gerthoux, P. M., Lukinmaa, P. L., Kovero, O., Needham, L., et al. (2004). Developmental dental aberrations after the dioxin accident in Seveso. Environ. Health Perspect. 112, 1313-1318. doi: 10.1289/ehp.6920

Alaluusua, S., Kiviranta, H., Leppaniemi, A., Hölttä, P., Lukinmaa, P. L., Lope, L., et al. (2002). Natal and neonatal teeth in relation to environmental toxicants. Pediatr. Res. 52, 652-655. doi: 10.1203/00006450-200211000-00008

Alaluusua, S., Lukinmaa, P. L., Torppa, J., Tuomisto, J., and Vartiainen, T. (1999). Developing teeth as biomarker of dioxin exposure. Lancet 353, 206. doi: 10.1016/S0140-6736(05)77214-7

Bartlett, J. D., and Simmer, J. P. (2014). Kallikrein-related peptidase-4 (KLK4): role in enamel formation and revelations from ablated mice. Front. Physiol. 5:240. doi: $10.3389 /$ fphys.2014.00240

Berdal, A., Hotton, D., Pike, J. W., Mathieu, H., and Dupret, J. M. (1993). Celland stage-specific expression of vitamin D receptor and calbindin genes in rat incisor: regulation by 1,25-dihydroxyvitamin D3. Dev. Biol. 155, 172-179. doi: 10.1006/dbio.1993.1016

Bloch-Zupan, A., Décimo, D., Loriot, M., Mark, M. P., and Ruch, J. V. (1994). Expression of nuclear retinoic acid receptors during mouse odontogenesis. Differentiation 57, 195-203. doi: 10.1046/j.1432-0436.1994.5730195.x

Braun, J. M. (2017). Early-life exposure to EDCs: role in childhood obesity and neurodevelopment. Nat. Rev. Endocrinol. 13, 161-173. doi: 10.1038/nrendo.2016.186

Calafat, A. M., Weuve, J., Ye, X., Jia, L. T., Hu, H., Ringer, S., et al. (2009). Exposure to bisphenol $\mathrm{A}$ and other phenols in neonatal intensive care unit premature infants. Environ. Health Perspect. 117, 639-644. doi: 10.1289/ehp.0800265

Chan, H. C., Estrella, N. M., Milkovich, R. N., Kim, J. W., Simmer, J. P., and Hu, J. C. (2011). Target gene analyses of 39 amelogenesis imperfecta kindreds. Eur. J. Oral Sci. 119(Suppl. 1), S311-S323. doi: 10.1111/j.1600-0722.2011.00857.x

Chaussain, C., Bouazza, N., Gasse, B., Laffont, A. G., Opsahl Vital, S., Davit-Béal, T., et al. (2014). Dental caries and enamelin haplotype. J. Dent. Res. 93, 360-365. doi: $10.1177 / 0022034514522060$

Cooper, J. E., Kendig, E. L., and Belcher, S. M. (2011). Assessment of bisphenol A released from reusable plastic, aluminium and stainless steel water bottles. Chemosphere 85, 943-947. doi: 10.1016/j.chemosphere.2011.06.060

Delfosse, V., Grimaldi, M., Pons, J. L., Boulahtouf, A., le Maire, A., Cavailles, V., et al. (2012). Structural and mechanistic insights into bisphenols action provide guidelines for risk assessment and discovery of bisphenol A substitutes. Proc. Natl. Acad. Sci. U.S.A. 109, 14930-14935. doi: 10.1073/pnas.12035 74109

Denis, M., Atlan, A., Vennat, E., Tirlet, G., and Attal, J. P. (2013). White defects on enamel: diagnosis and anatomopathology: two essential factors for proper treatment (part 1). Int. Orthod. 11, 139-165. doi: 10.1016/j.ortho.2013.02.014

Duty, S. M., Mendonca, K., Hauser, R., Calafat, A. M., Ye, X., Meeker, J. D., et al. (2013). Potential sources of bisphenol A in the neonatal intensive care unit. Pediatrics 131, 483-489. doi: 10.1542/peds.2012-1380

Farah, R. A., Monk, B. C., Swain, M. V., and Drummond, B. K. (2010). Protein content of molar-incisor hypomineralisation enamel. J. Dent. 38, 591-596. doi: $10.1016 /$ j.jdent.2010.04.012 drafted, read the paper and made helpful suggestions to improve the paper. All authors approved the final version to be published.

\section{FUNDING}

This work was funded by the University Paris-Diderot, the French National Institute of Health and Medical Research (INSERM).

Gibson, C. W., Collier, P. M., Yuan, Z. A., Chen, E., Adeleke-Stainback, P., Lim, J., et al. (1997). Regulation of amelogenin gene expression. Ciba Found. Symp. 205, 187-97; discussion 197-9.

Gore, A. C., Chappell, V. A., Fenton, S. E., Flaws, J. A., Nadal, A., Prins, G. S., et al. (2015). EDC-2: the endocrine society's second scientific statement on endocrine-disrupting chemicals. Endocr. Rev. 36, E1-E150. doi: 10.1210/er.2015-1093

Houari, S., Loiodice, S., Jedeon, K., Berdal, A., and Babajko, S. (2016). Expression of steroid receptors in ameloblasts during amelogenesis in rat incisors. Front. Physiol. 7:503. doi: 10.3389/fphys.2016.00503

Hu, J. C., Hu, Y., Lu, Y., Smith, C. E., Lertlam, R., Wright, J. T., et al. (2014). Enamelin is critical for ameloblast integrity and enamel ultrastructure formation. PLoS ONE 9:e89303. doi: 10.1371/journal.pone.0089303

Jälevik, B., Dietz, W., and Norén, J. G. (2005). Scanning electron micrograph analysis of hypomineralized enamel in permanent first molars. Int. J. Paediatr. Dent. 15, 233-240. doi: 10.1111/j.1365-263X.2005.00644.x

Jan, J., Sovcikova, E., Kocan, A., Wsolova, L., and Trnovec, T. (2007). Developmental dental defects in children exposed to PCBs in eastern Slovakia. Chemosphere 67, S350-S354. doi: 10.1016/j.chemosphere.2006.05.148

Jedeon, K., De la Dure-Molla, M., Brookes, S. J., Loiodice, S., Marciano, C., Kirkham, J., et al. (2013). Enamel defects reflect perinatal exposure to bisphenol A. Am. J. Pathol. 83, 108-118. doi: 10.1016/j.ajpath.2013.04.004

Jedeon, K., Houari, S., Loiodice, S., Thuy, T. T., Le Normand, M., Berdal, A., et al. (2016a). Chronic exposure to bisphenol A exacerbates dental fluorosis in growing rats. J. Bone Miner. Res. 31, 1955-1966. doi: 10.1002/jbmr.2879

Jedeon, K., Loiodice, S., Le Normand, M., Houari, S., Chaloyard, J., Salhi, K., et al. (2016b). Androgen receptor involvement in rat amelogenesis: an additional way for endocrine disrupting chemicals to affect enamel synthesis. Endocrinology 157, 4287-4296. doi: 10.1210/en.2016-1342

Jedeon, K., Loiodice, S., Marciano, C., Vinel, A., Canivenc Lavier, M. C., Berdal, A., et al. (2014b). Estrogen and bisphenol A affect male rat enamel formation and promote ameloblast proliferation. Endocrinology 155, 3365-3375. doi: 10.1210/en.2013-2161

Jedeon, K., Marciano, C., Loiodice, S., Boudalia, S., Canivenc Lavier, M.-C., Berdal, A., et al. (2014a). Enamel hypomineralization due to endocrine disruptors. Conn. Tiss. Res. 55, 1-5. doi: 10.3109/03008207.2014.923857

Jeremias, F., Koruyucu, M., Küchler, E. C., Bayram, M., Tuna, E. B., Deeley, K., et al. (2013). Genes expressed in dental enamel development are associated with molar-incisor hypomineralization. Arch. Oral Biol. 58, 1434-1442. doi: 10.1016/j.archoralbio.2013.05.005

Johns, L. E., Ferguson, K. K., and Meeker, J. D. (2016). Relationships between urinary phthalate metabolite and bisphenol A concentrations and vitamin D levels in U.S. Adults: National Health and Nutrition Examination Survey (NHANES), 2005-2010. J. Clin. Endocrinol. Metab. 101, 4062-4069. doi: $10.1210 /$ jc. $2016-2134$

Koch, G., Hallonsten, A. L., Ludvigsson, N., Hansson, B. O., Holst, A., and Ullbro, C. (1987). Epidemiologic study of idiopathic enamel hypomineralization in permanent teeth of Swedish children. Commun. Dent. Oral Epidemiol. 15, 279-285. doi: 10.1111/j.1600-0528.1987.tb00538.x

Kühnisch, J., Thiering, E., Kratzsch, J., Heinrich-Weltzien, R., Hickel, R., and Heinrich, J. (2015). GINIplus study group; LISAplus study group. Elevated serum 25(OH)-vitamin D levels are negatively correlated with molar-incisor hypomineralization. J. Dent. Res. 94, 381-387. doi: 10.1177/0022034514561657 
Laisi, S., Ess, A., Sahlberg, C., Arvio, P., Lukinmaa, P. L., and Alaluusua, S. (2009). Amoxicillin may cause molar incisor hypomineralization. J. Dent. Res. 88, 132-136. doi: 10.1177/0022034508328334

Li, L., Wang, Q., Zhang, Y., Niu, Y., Yao, X., and Liu, H. (2015). The molecular mechanism of bisphenol A (BPA) as an endocrine disruptor by interacting with nuclear receptors: insights from molecular dynamics (MD) simulations. PLoS ONE 10:e0120330. doi: 10.1371/journal.pone.0120330

Lindemeyer, R. G., Gibson, C. W., and Wright, T. J. (2010). Amelogenesis imperfecta due to a mutation of the enamelin gene: clinical case with genotypephenotype correlations. Pediatr. Dent. 32, 56-60.

Liu, X., Matsushima, A., Nakamura, M., Costa, T., Nose, T., and Shimohigashi, Y. (2012). Fine spatial assembly for construction of the phenol pocket to capture bisphenol $\mathrm{A}$ in the human nuclear receptor estrogen related receptor $\gamma$.J. Biochem. 151, 403-415. doi: 10.1093/jb/mvs008

Mishra, A., and Pandey, R. K. (2016). Molar incisor hypomineralization: an epidemiological study with prevalence and etiological factors in Indian pediatric population. Int. J. Clin. Pediatr. Dent. 9, 167-171. doi: 10.5005/jp-journals-10005-1357

Morkmued, S., Laugel-Haushalter, V., Mathieu, E., Schuhbaur, B., Hemmerlé, J., Dollé, P., et al. (2017). Retinoic acid excess impairs amelogenesis inducing enamel defects. Front. Physiol. 7:673. doi: 10.3389/fphys.2016.00673

Papagerakis, P., MacDougall, M., and Berdal, A. (2002). Differential epithelial and mesenchymal regulation of tooth-specific matrix proteins expression by 1,25-dihydroxyvitamin D3 in vivo. Connect. Tissue Res. 43, 372-375. doi: 10.1080/03008200290000655

Pawlicki, R., Knychalska-Karwin, Z., Stankiewicz, D., Jakób-Dolezal, K., and Karwan, T. (1992). Disturbances of mineral metabolism in teeth of rats receiving corticosteroids for 3 generations. Folia Histochem. Cytobiol. 30, 75-78.

Poimenova, A., Markaki, E., Rahiotis, C., and Kitraki, E. (2010). Corticosterone-regulated actions in the rat brain are affected by perinatal exposure to low dose of bisphenol A. Neuroscience 167, 741-749. doi: 10.1016/j.neuroscience.2010.02.051

Pupo, M., Pisano, A., Lappano, R., Santolla, M. F., De Francesco, E. M., Abonante, S., et al. (2012). Bisphenol A induces gene expression changes and proliferative effects through GPER in breast cancer cells and cancer-associated fibroblasts. Environ. Health Perspect. 120, 1177-1182. doi: 10.1289/ehp.1104526

Rehan, M., Ahmad, E., Sheikh, I. A., Abuzenadah, A. M., Damanhouri, G. A., Bajouh, O. S., et al. (2015). Androgen and progesterone receptors are targets for Bisphenol A (BPA), 4-methyl-2,4-bis-(P-Hydroxyphenyl)Pent-1-Ene-A potent metabolite of BPA, and 4-Tert-Octylphenol: a computational insight. PLoS ONE 10:e0138438. doi: 10.1371/journal.pone.0138438

Sahlberg, C., Pavlic, A., Ess, A., Lukinmaa, P. L., Salmela, E., and Alaluusua, S. (2013). Combined effect of amoxicillin and sodium fluoride on the structure of developing mouse enamel in vitro. Arch. Oral Biol. 58, 1155-1164. doi: 10.1016/j.archoralbio.2013.03.007

Salmela, E., Lukinmaa, P. L., Partanen, A. M., Sahlberg, C., and Alaluusua, S. (2011). Combined effect of fluoride and 2,3,7,8-tetrachlorodibenzo-p-dioxin on mouse dental hard tissue formation in vitro. Arch. Toxicol. 85, 953-963. doi: 10.1007/s00204-010-0619-4

Serna, C., Vicente, A., Finke, C., and Ortiz, A. J. (2016). Drugs related to the etiology of molar incisor hypomineralization: a systematic review. J. Am. Dent. Assoc. 147, 120-130. doi: 10.1016/j.adaj.2015.08.011

Silva, M. J., Scurrah, K. J., Craig, J. M., Manton, D. J., and Kilpatrick, N. (2016). Etiology of molar incisor hypomineralization - A systematic review. Commun. Dent. Oral Epidemiol. 44, 342-353. doi: 10.1111/cdoe. 12229

Solomon, G. M., and Weiss, P. M. (2002). Chemical contaminants in breast milk: time trends and regional variability. Environ. Health Perspect. 110, A339-A347. doi: 10.1289/ehp.021100339

Sönmez, H., Yıldırım, G., and Bezgin, T. (2013). Putative factors associated with molar incisor hypomineralisation: an epidemiological study. Eur. Arch. Paediatr. Dent. 14, 375-380. doi: 10.1007/s40368-013-0012-0

Tourino, L. F., Corrêa-Faria, P., Ferreira, R. C., Bendo, C. B., Zarzar, P. M., and Vale, M. P. (2016). Association between molar incisor hypomineralization in schoolchildren and both prenatal and postnatal factors: a population-based study. PLoS ONE 11:e0156332. doi: 10.1371/journal.pone.0156332

Varayoud, J., Ramos, J. G., Munoz-de-Toro, M., and Luque, E. H. (2014). Longlasting effects of neonatal bisphenol A exposure on the implantation process. Vitam. Horm. 94, 253-275. doi: 10.1016/B978-0-12-800095-3.00010-9

Weerheijm, K. L., Jalevik, B., and Alaluusua, S. (2001). Molar-incisor hypomineralisation. Caries Res. 35, 390-391. doi: 10.1159/000047479

Weerheijm, K. L., and Merjare, I. (2003). Molar incisor hypomineralisation: a questionnaire inventory on its occurrence in member countries of the European Academy of Paediatric Dentistry (EAPD). Int. J. Paediatr. Dent. 13, 411-416. doi: 10.1046/j.1365-263X.2003.00498.x

Conflict of Interest Statement: The authors declare that the research was conducted in the absence of any commercial or financial relationships that could be construed as a potential conflict of interest.

Copyright (C) 2017 Babajko, Jedeon, Houari, Loiodice and Berdal. This is an openaccess article distributed under the terms of the Creative Commons Attribution License (CC BY). The use, distribution or reproduction in other forums is permitted, provided the original author(s) or licensor are credited and that the original publication in this journal is cited, in accordance with accepted academic practice. No use, distribution or reproduction is permitted which does not comply with these terms. 